\title{
Small fiber degeneration in post-stroke complex regional pain syndrome I
}

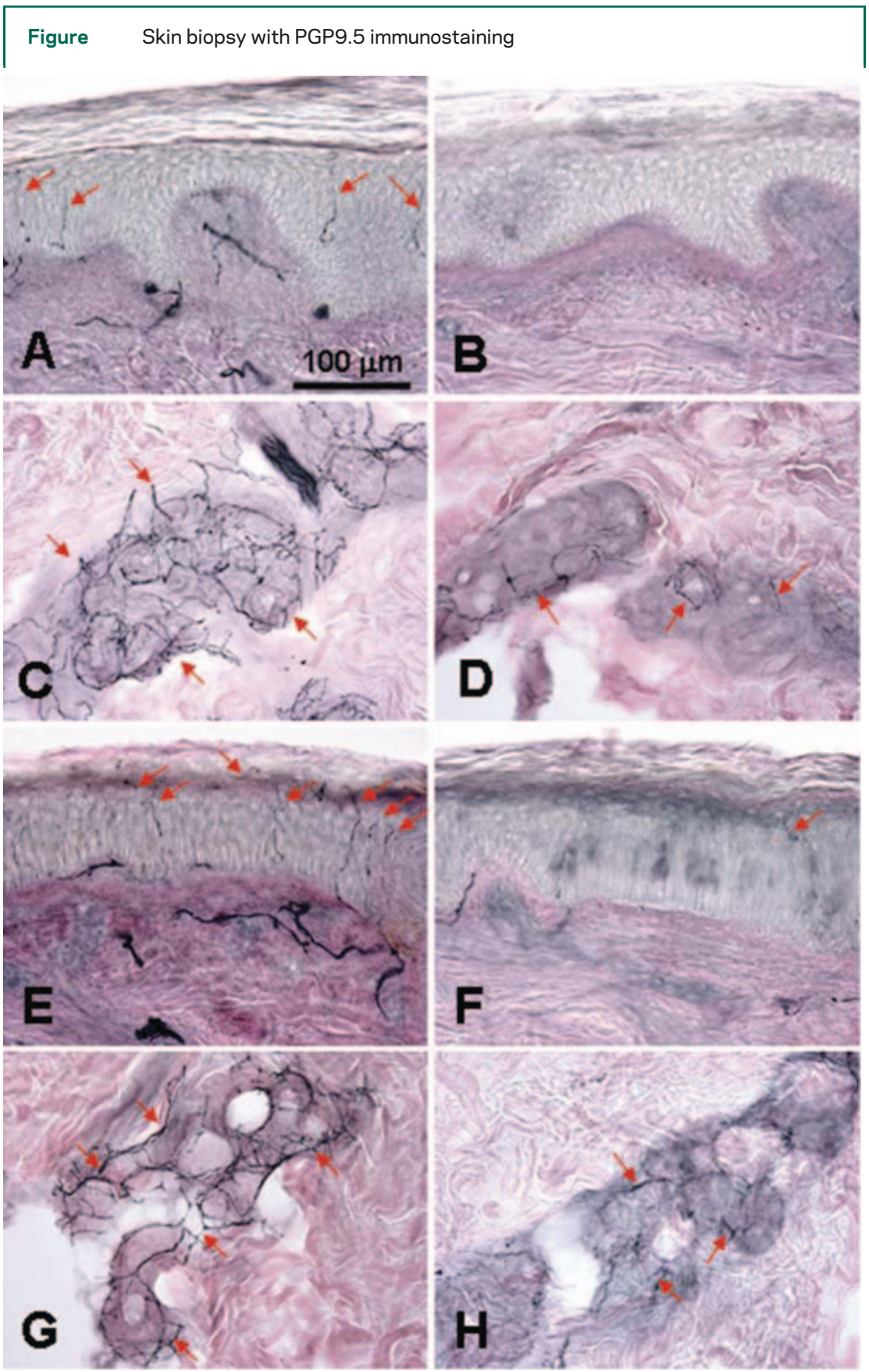

Intraepidermal C-fibers were present (arrows) at normal densities ( $\geq 5$ fibers $/ \mathrm{mm}$ ) at the right foot (A, 7.2 fibers $)$ $\mathrm{mm})$ and $\mathrm{DL}$ ( $E, 11.1$ fibers) $\mathrm{mm})$, but were absent at the left foot (B) and reduced at the DL (F, 2.1 fibers $/ \mathrm{mm}$ ) Sudomotor autonomic C fibers (arrows) were markedly reduced at the left foot (D) and $\mathrm{DL}(\mathrm{H})$ as compared to the right $(\mathrm{C}, \mathrm{G})$.

A 37-year-old man had a massive right middle cerebral artery infarct causing left hemiparesis. He developed chronic poststroke complex regional pain syndrome type I (CRPS I) of the left foot and distal leg (DL) with pain, allodynia, edema, skin hyperemia, and hair loss. Vascular studies and an EMG were normal. Skin biopsy with PGP9.5 immunostaining showed complete loss of intraepidermal somatic C-fibers at the left foot (figure, B) and reduced density at the DL (figure, F). Sudomotor autonomic C-fibers were also mark- 
edly reduced at the left foot (figure, D) and DL (figure, H) compared to the right. CRPS I could be associated with degeneration of peripheral somatic ${ }^{1}$ and autonomic small fibers.

Kamal R. Chémali, $M D$; and Lan Zhou, $M D, P h D$, Cleveland, $\mathrm{OH}$

Disclosure: The authors report no conflicts of interest.

Address correspondence and reprint requests to Dr. Kamal R. Chémali, Staff Neurologist, Department of Neurology/Neurological Institute, Cleveland Clinic, 9500 Euclid Ave/S90, Cleveland, OH 44195; chemalk@ccf.org

\section{REFERENCE}

1. Oaklander AL, Rissmiller JG, Gelman LB, Zheng L, Chang Y, Gott R. Evidence of focal small-fiber axonal degeneration in complex regional pain syndrome-I (reflex sympathetic dystrophy). Pain 2006;120:235-243. 


\section{Neurology}

\section{Small fiber degeneration in post-stroke complex regional pain syndrome I Kamal R. Chémali and Lan Zhou \\ Neurology 2007;69;316-317 \\ DOI 10.1212/01.wnl.0000266967.38657.3a}

This information is current as of July 16, 2007

\section{Updated Information \& Services}

References

Permissions \& Licensing

Reprints including high resolution figures, can be found at: http://n.neurology.org/content/69/3/316.full

This article cites 1 articles, 0 of which you can access for free at: http://n.neurology.org/content/69/3/316.full\#ref-list-1

Information about reproducing this article in parts (figures,tables) or in its entirety can be found online at: http://www.neurology.org/about/about_the_journal\#permissions

Information about ordering reprints can be found online: http://n.neurology.org/subscribers/advertise

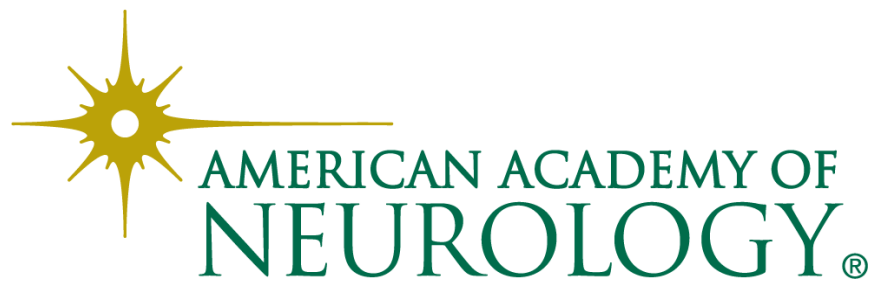

